\title{
The accuracy of Altman's models in predicting hotel bankruptcy
}

\author{
Mihail Diakomihalis \\ Accounting Department, Technological Educational Institute of Epirus \\ Psathaki, 48100 Preveza, Greece \\ Tel. +30-26820-50554, E-mail: diakomnisyros@ gmail.com
}

Received: September 12, 2012 Accepted: October 16, 2012 DOI: 10.5296/ijafr.v2i2.2367

\begin{abstract}
This paper studies the bankruptcy predictions for different hotel categories in Greece, aiming to determine the zone of discrimination classified as "certainty" for bankruptcy. It also calculates the differentiation degree of the bankruptcy risk that is owed to the different categorisation of the hotels. The three versions of Altman's model have been applied to evaluate the bankruptcy prediction and its accuracy between the hotel enterprises that fall in the "distress" zone. Approximately 40 percent of the total firms in the distress zone are evaluated, having a $\mathrm{Z} 1$ score below 1.8 , while the percentage for the $\mathrm{Z} 2$ formula is 44.5 percent and 36.3 percent for the $\mathrm{Z} 3$ score. The $\mathrm{Z} 1$ score formula is more precise - with an accuracy rate of 88.2 percent in 2007, one year before bankruptcy - than the Z2 model, which gives a prediction of 83.33 percent for the cutoff zone $<0.7$, while the $\mathrm{Z} 3$ score reaches 80 percent prediction for the $<0.5$ zone. Five and three star hotels show a higher bankruptcy risk than 4-star hotels, while the smaller risk is depicted in 2-star hotels. This paper fulfils the identified need to predict the certainty of bankruptcy among enterprises in the distress zone.
\end{abstract}

Keywords: Financial analysis, bankruptcy, Altman's models, hotel sector 


\section{Introduction}

Financial accounting is important to all firms, since it provides essential data for executive financial decisions. Therefore financial managers in modern enterprises should develop their business analysis and problem solving skills (Mattimoe, 2008; Scapens, 2006; Burns, 2003; Burns and Balvinsdottir, 2005), without limiting their duties in verifying accounting data.

The picture of prosperity and financial robustness that every enterprise reflects is affected by the estimation of its position formed by investors, creditors and stakeholders (Lazaridis and Papadopoulos, 2002; Ryu and Jang, 2004). A great deal of the financial analysis research carried out on an international level deals with the investigation of precognition of economic failure (Vranas, 1991).

The possession and maintenance of cash is considered important for all enterprises, independent of their size, not only for the success of business activity, but mainly as an essential condition of survival (DeFranco and Schmidgall, 1998). Many studies of enterprises in different sectors have stressed the great importance of cash flow (Bohannon and Edwards, 1993; Casey and Bartczak, 1985; DeFranco and Schmidgall, 1998; Epstein and Pava, 1994; Mills and Yamamura, 1998; Schmidgall, et al., 1993; Sylvestre and Urbancic, 1994), to the extent that it is used to determine the difference between successful management and bankruptcy (Beck, 1994).

The ability to predict bankruptcy may be important for financial users, but it also may be crucial for groups such as investors, creditors, stakeholders, credit rating agencies, auditors, and regulators (Lifschutz and Jacobi, 2010). Predicting bankruptcy as early as possible is always important, but it is considered especially vital in periods of financial and economic crisis. However, financial accounting might be considered of greater or equal importance to hotel enterprise development, because it provides information to interested parties such as the state, credit organizations, and other tourist enterprises.

The hotel sector is one of many core sectors that form the idiomorphic tourist product, which participates in the tourist activity by producing and offering some of the most fundamental products of the tourism industry. The financing needs for investments in fixed assets, which require the bulk of the capital invested in the hotel sector, in combination with the continuity of hotel activity, increase fixed costs considerably; fixed costs must be covered irrespective of the volume of the hotel turnover (Mattimoe, 2008). Bankruptcy forecasting models prove that the main cause of bankruptcy is poor financial management of a firm. The data published on financial reports such as balance-sheets and profit \& loss statements, along with the financial ratio analysis, may contribute significantly to the investigation and ascertainment of the robustness and prospects of hotel enterprises.

The most important financial ratios come from the solvency category (e.g., WC/TA, TD/TA), without underestimating the importance of profitability ratios, which indicate the dependence of a firm's viability on profit making (Dimitras et al., 1996:493)

Despite the abundance of studies that have investigated the failures of individual firms, there are only a few documented business failure prediction studies for the hospitality industry $(\mathrm{Gu}$, 2002:28), and even fewer in the Greek lodging sector. 
Diakomihalis' (2011) study of the Greek hotel sector revealed a failure prediction of the Greek hotel firms, using the Altman discriminant analysis model, which was developed for public manufacturing companies.

The research question raised in this paper is: How accurate are the various versions of the Altman model on forecasting financial failure of private hotel companies in Greece today? Will prediction failure results differ from the application of the Altman's two alternative models - one of which is developed for private firms (as all hotel enterprises of the present research are) and the other that was developed for non-manufacturer industrials and emerging market credits - where hotels in the the tourist industry could also be included? Which may be the most precise cut-off zone for the three Altman models of business failure certainty?

Several researchers have raised questions in the literature about the influence of factors such as hotel category on financial ratios (Collier and Gregory, 1995; Min et al., 2009; Pavlatos and Paggios, 2009; Barjaktarovic and Barjaktarovic, 2010). To the main question of this research, therefore, the role of the hotel category in bankruptcy prediction should be added.

The present research deals with the financial analysis of hotel's financial statements, aiming to contribute to the accuracy of predicting hotel bankruptcy. The specific objective of the study is to determine the zone in each one of the three Altman's models in which the bankruptcy of enterprises reaches a higher accuracy. Also, the differentiation degree of the bankruptcy risk that is owed to the categorization of the hotels is also a subject of this study.

This study contributes to the literature related to the financial indicators and the bankruptcy forecast. Most studies that have examined the predictive ability of the Altman Model were performed in developed countries such the U.S. and U.K. (Lifschutz and Jacobi, 2010), while the present study focuses on a EU-member country, Greece, which is going through a great economic crisis that started in 2008, making hotel stockholders more sceptical than before when predicting the future of their investment in Greek hotels. Additionally, foreign investors' interest in investing in the Greek tourism market has increased recently, making the bankruptcy forecasting analysis for private hotel companies a precondition. Therefore it is critical to examine the predictive accuracy of Altman's models in Greece.

The empirical results contribute to evaluation of Altman's models as to their accuracy estimating the risk of bankruptcy for private hotel firms in Greece, enhancing the precision of forecasts and improving the opportunities for advisable interventions that could deter bankruptcy. The limitation of the research lies in the requirement of the evaluation of other factors as well, such as the size of hotels and their geographic location, the estimation of which may lead to different results for different hotel enterprises.

\section{Bankruptcy Definitions}

The definition of business failure varies from one study to another, depending on the purpose and scope of each study (Beaver, 1966; Altman, 1968; Dimitras et al., 1996; Gu, 2002). In some research, business failure is defined as three consecutive years of negative net income (Cho, 1994; Pfeiffer, 2000; Youn and Gu, 2010). "Economic failure," "technical insolvency," and "bankruptcy" are the terminologies that represent business failure (Tavlin et al., 1989; Altman, 1993). 


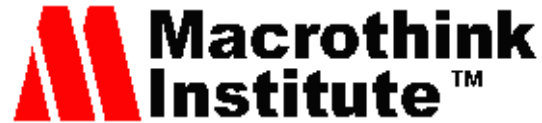

International Journal of Accounting and Financial Reporting ISSN 2162-3082

$\mathrm{Gu}$ (2002: 30) defines economic failure as the condition in which business expenses exceed revenues, technical insolvency as the situation of a firm with positive net worth and profits but not enough liquidity to meet current liabilities, and finally, bankruptcy as the condition with negative net worth and illiquidity that leads the firm through the legal process of reorganization or dissolving.

Altman defines economic failure as the situation of realized return on investment significantly and continually under prevailing return on similar investments. Insolvency is considered a lack of liquidity and the inability of a firm to meet its current obligations. In a bankruptcy condition, a business enterprise cannot meet its debt obligations and petitions a federal district court for either reorganization of its debts or liquidation of its assets ( Kim and $\mathrm{Gu}, 2006:$ 478). In summary, it might be concluded that a firm is considered to be in a state of bankruptcy when and if it is unable to pay off its debts and, thereafter, being under constraint, legally declares its inability to continue business.

\section{Literature Review}

Bankruptcy prediction has long attracted the interest of researchers. The difficulty calculating the results of insolvency prediction models is one of the reasons these models have not gained greater use. With the technology development the use of bankruptcy prediction models has become practical and accessible for everyone. The difficulty collecting data on the corresponding sets of failed and successful enterprises constitutes one of the main problems in developing and testing bankruptcy forecasting models.

Over the past 50 years, a plethora of studies have used a great variety of bankruptcy prediction models to investigate the failures of individual firms (Youn and $\mathrm{Gu}, 2010$; Bellovary et al., 2007). Among the vast number of studies that have assessed bankruptcy since 1965, very few of them were applied to hospitality firms (lodging and restaurant) (Gu and Gao, 2000; Gu, 2002; Kim, H., Gu, Z., 2006). Some of the most recent studies of lodging business failure prediction are:

Youn and $\mathrm{Gu}$ (2007) tested the prediction of business failure in the Korean lodging industry and concluded that Korean lodging firms "should lower their reliance on debt financing and increase the efficiency in using existing assets to generate sales revenue."

Youn and Gu (2010) found the Artificial Neural Networks ( ANN) model advantageous over the logistic regression model in prediction accuracy. They concluded that interest coverage is the most important signal of business failure for the Korean hotel industry, proposing Korean lodging firms should increase the interest coverage. The ability to service debts and productivity of profits is regarded as a survival indicator of Korean hotel firms.

Soo Y. Kim (2011) tested the application of multivariate discriminant analysis, logistic, artificial neural networks (ANNs), and support vector machine (SVM) models in hotel bankruptcy prediction, and considered ANN as best early warning technique that performs accurately with small relative error costs for hotel bankruptcy prediction.

Among the many prediction models that have been developed, the far-famed is that by Edward I. Altman (1968). Being the first person to successfully develop multiple discriminate 


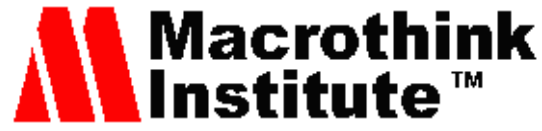

International Journal of Accounting and Financial Reporting ISSN 2162-3082 2012, Vol. 2, No. 2

analysis prediction model with a degree of $95.0 \%$ rate of accuracy, he is considered the pioneer of insolvency predictors (Altman, 1968). Altman incorporated in his model financial ratios concerning to liquidity, profitability, financial leverage, activity and solvency. The accounting researcher William Beaver $(1967,1968)$ was the first to apply a number of ratios which could discriminate between failed and non failed companies up to five years prior to bankruptcy. Altman improved Beaver's method, applying a discriminant analysis using five multiple variables.

Altman's models have been applied successfully in many studies worldwide concerning the subjects of capital structure and strategic management (Allayannis et al., 2003; Molina, 2005; Calandro, 2007), investment decisions (Sudarsanam and Lai, 2001; Lawson, 2008), asset and credit risk estimation (Kao, 2000; Griffin and Lemmon, 2002; Ferguson and Shockley, 2003; Jayadev, 2006), distressed securities (Marchesini et al., 2004, Gerantonis et al. 2009), and financial failure of publicly traded companies (Lifschutz and Jacobi, 2010).

After the 80's appeared different methods than the discriminant analysis for the prediction of business failure (Dimitras et al, 1996:493). Analysis of accuracy of the models in papers published from 1965 to 2007, shows that in $38 \%$ of the studies used multivariate discriminant analysis, suggesting that multivariate discriminant analysis and neural networks are the most promising methods for bankruptcy prediction models (Bellovary et al., 2007:1 \& 6).

In all cases, the techniques used to develop predictive models are considered tools of analysis that are not intended to replace personal evaluations based on experience and information. Properly used, each model is a filter for the localisation of enterprises that need further investigation or have presented a concrete tendency toward bankruptcy for several years. The prompt detection of problematic enterprises with downward tendencies can ward off bankruptcy if essential corrective adjustments are made.

A statistical model, such as multivariable discriminant analysis (MDA), could be a good improvement over unsophisticated ratio analysis for lodging industry bankruptcy prediction (Gu 2002:28). The MDA introduced by Altman has been applied thereafter to predict business failures by a number of researchers, among which are Begley et al. (1996), Beynon and Peel (2001), Neophytou et al. (2001), Perez (2006), Aziz and Dar (2006), Agarwal and Taffler, (2007) and Chung et al. (2008). The study of Lifschutz and Jacobi (2010) showed that the predictive ability of the original Altman Model for publicly traded companies is very high with respect to bankrupt companies.

Among the limited studies concerning the Greek firms are those of Gloubos and Grammatikos (1988), Theodossiou (1991), Dimitras, et al. (1996 and 1999), Zopounidis and Doumpos (1999), and the most recent by Gerantonis et al. (2009), where all listed in the Athens Exchange companies, during 2002 - 2008 and discontinuations of operation of these companies during the same period were examined, with accuracy rate of $54 \%$ of failed companies one year before bankruptcy. None of these studies though focused on hospitality sector firms. 


\section{Mll Macrothink}

International Journal of Accounting and Financial Reporting

ISSN 2162-3082

2012, Vol. 2, No. 2

\section{Methodology and Sample}

The multivariable model of discriminant analysis initially applied by Altman, as well as the alternative versions of the initial model developed later, will be applied in the present study. The accuracy in bankruptcy prediction of the initial test of Altman Z-Score reached 72\%, two years prior to bankruptcy (Altman, 1968), while on a series of subsequent tests covering three different time periods, up until 1999, the accuracy in predicting bankruptcy one year ahead, ranged between $80-90 \%$ (Altman, 2000). The Z-score models became widely used tool for accountants, auditors, and borrowers for loan evaluation since 1985 up to present (Eidleman, 1995). The first model was based on data from public manufacturing companies, while the modified versions by Altman have been designed to be applicable to private industrial and non-industrial companies, as well as to service-sector companies.

\section{1) The original Z 1 -score formula for predicting bankruptcy has been introduced} by Edward Altman in 1968, when it was used to predict the bankruptcy probability of a firm within two years. It is a linear combination of five financial ratios, concerning multiple corporate income and balance sheet values which can measure the financial health of a company, weighted by coefficients.

\section{The $\mathrm{Z}$ 1-score discriminant formula developed by Altman is:}

$\mathrm{Z}=1.2 \mathrm{~T}_{1}+1.4 \mathrm{~T}_{2}+3.3 \mathrm{~T}_{3}+0.6 \mathrm{~T}_{4}+0.999 \mathrm{~T}_{5}$.

$\mathrm{T}_{1}=$ Working Capital $/$ Total Assets. This variable measures the relation of liquid assets to the total assets of a company. Working capital is measured by subtracting current liabilities from current assets.

$\mathrm{T}_{2}=$ Retained Earnings / Total Assets. Retained earnings or earned surplus is the total amount of earnings and / or losses of a company in its lifetime period. The ratio is also used to measure the Leverage of an enterprise, which is the portion of assets financed through retained earnings compared to debt financing.

$\mathrm{T}_{3}=$ Earnings Before Interest and Taxes / Total Assets. It measures the real productivity of a firm independently of taxes and interest. This is an exceptionally suitable ratio for business failure prediction.

$\mathrm{T}_{4}=$ Market Value of Equity / Book Value of Total Liabilities. It is measured based on the market value of all stock shares on one hand and on the current value of short and long term liabilities.

$\mathrm{T}_{5}=$ Sales/total assets. Capital turnover ratio measures the degree of utilisation of total assets of an enterprise in connection with the realised sales.

The zones of discrimination that depend on the $\mathrm{Z} 1$ score are:

Z 1> 2.99 - Safe Zone

$1.8<$ Z $1<2.99$ - Grey Zone

Z $1<1.80$ - Distress Zone 


\section{Macrothink}

International Journal of Accounting and Financial Reporting

ISSN 2162-3082 2012, Vol. 2, No. 2

When the overall index $\mathrm{Z} 1$ is more than 2.99, an enterprise is considered in the safe zone, with a very low risk of bankruptcy. When a $\mathrm{Z} 1$ score is greater than 1.80 and less than 2.99 , a company is considered to be in the grey zone, since there is no strong indication of a bankruptcy risk level. A Z 1score index less than 1.80 indicates a strong possibility of failure and placement in the distress zone $(\mathrm{Z} 1<1.80)$.

\section{2) Z 2 -score estimated for private firms (Altman, 1983)}

$\mathrm{T}_{1}=($ Current assets-current liabilities $) /$ total assets

$\mathrm{T}_{2}=$ Retained earnings/total assets

$\mathrm{T}_{3}=$ Earnings before interest and taxes/total assets

$\mathrm{T}_{4}=$ Book value of equity/total liabilities

$\mathrm{T}_{5}=$ Sales/total assets

\section{Z 2 Score Bankruptcy Model:}

$\mathrm{Z} 2=0.717 \mathrm{~T}_{1}+0.847 \mathrm{~T}_{2}+3.107 \mathrm{~T}_{3}+0.420 \mathrm{~T}_{4}+0.998 \mathrm{~T}_{5}$

The zones of discrimination depending on the $\mathrm{Z} 2$ score are:

Z $2>2.9$ - Safe Zone

$1.23<\mathrm{Z} 2<2.9$ - Grey Zone

Z $2<1.23$ - Distress Zone

\section{3) Z 3 -score estimated for non-manufacturer industrials and emerging market credits}

$\mathrm{T}_{1}=($ Current assets-current liabilities $) /$ total assets

$\mathrm{T}_{2}=$ Retained earnings/total assets

$\mathrm{T}_{3}=$ Earnings before interest and taxes/total assets

$\mathrm{T}_{4}=$ Book value of equity/total liabilities

\section{Z 3 -Score Bankruptcy Model:}

$\mathrm{Z} 3=6.56 \mathrm{~T}_{1}+3.26 \mathrm{~T}_{2}+6.72 \mathrm{~T}_{3}+1.05 \mathrm{~T}_{4}$

The zones of discrimination depending on the $\mathrm{Z} 3$ score are:

Z 3 > 2.6 - Safe Zone

$1.1<\mathrm{Z} 3<2.6$ - Grey Zone

Z $3<1.1$ - Distress Zone

The study is conducted for 2007 , which was selected because it is the last year before the 


\section{Macrothink}

International Journal of Accounting and Financial Reporting

ISSN 2162-3082

2012, Vol. 2, No. 2

economic crisis in Greece and other Eurozone countries that began in 2008. According to the objectives of this paper, every hotel of the country that keeps tax books of category $\mathrm{C}$ is included in the sample. The selection of financial statements took place by random stratification sampling in which approximately three hotels from every prefecture of the country were selected. The sample selected included 146 privately owned hotels from the entire Greek territory, which by category segmentation are: 30 five-star hotels, 29 four-star, 51 three-star and 36 two-star hotels.

\section{Results and Discussions}

Only four firms are registered on the Athens Exchange market. Therefore, the lack of knowledge of the market value of equity for all the firms in the sample led to the use of book value of equity for all businesses in the three models, considering the differentiation of the T4 variable as the main limitation of this research. Placing the corresponding financing indicators for the year examined, the models yielded the following results by hotel category and model:

Table 1. Z - Scores for Hotels of 5, 4, 3 and 2 stars, 2007, with 3 Bankruptcy Models

\begin{tabular}{|l|l|l|l|}
\hline \multirow{2}{*}{ HOTEL CATEGORY } & Z 1 & Z 2 & Z 3 \\
\cline { 2 - 4 } & Average Z Score & Average Z Score & Average Z Score \\
\hline 5 STAR & 1,914 & 1,451 & 2,969 \\
\hline 4 STAR & 4,172 & 3,048 & 7,269 \\
\hline 3 STAR & 4,493 & 3,247 & 2,919 \\
\hline 2 STAR & 9,092 & 6,489 & 6,087 \\
\hline AVERAGE & 4,918 & 3,375 & 3,622 \\
\hline
\end{tabular}




\section{Ml Macrothink}

International Journal of Accounting and Financial Reporting ISSN 2162-3082 2012, Vol. 2, No. 2

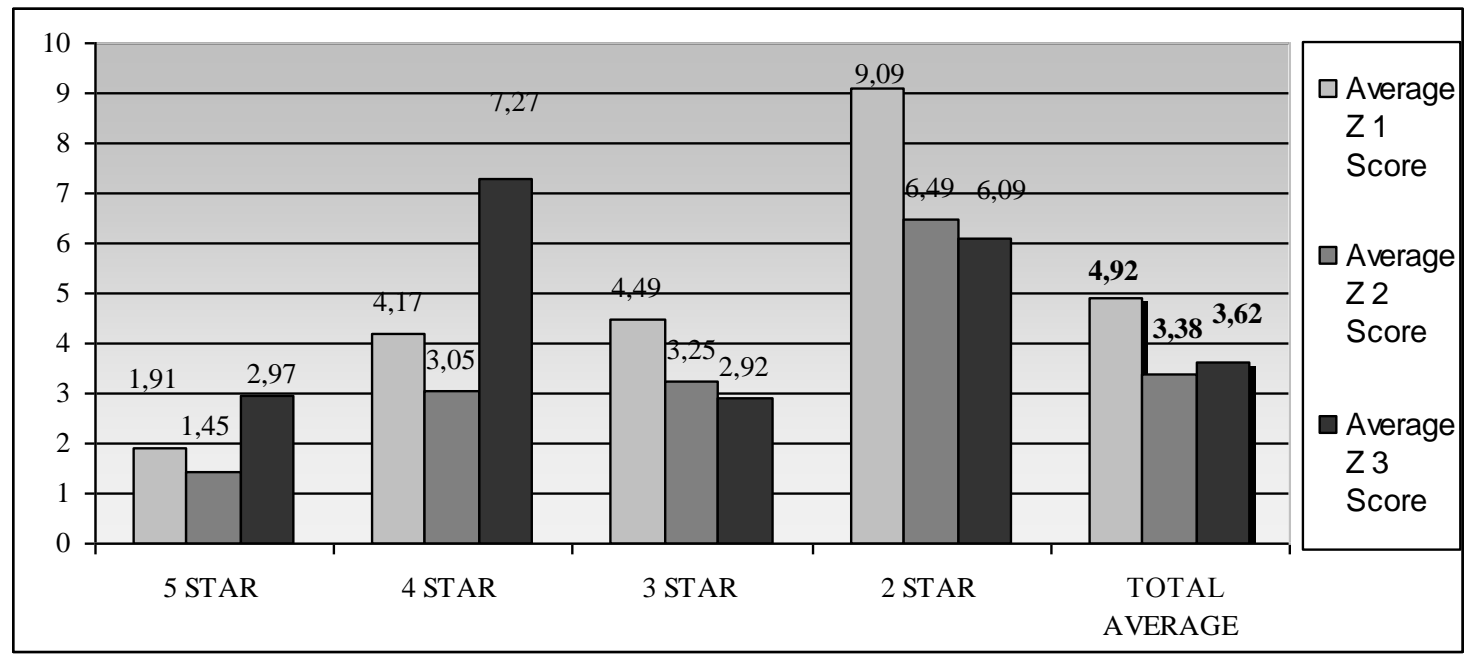

Figure 1. Average values of Z 1, Z 2 and Z 3 Scores

The number of firms and their percentage to total, belonging to each cut off distress zone, is presented by hotel category and for each one of the three models in Table 2:

Table 2. Z - Scores for Hotels of 5, 4, 3 and 2 stars, 2007, with 3 Bankruptcy Models

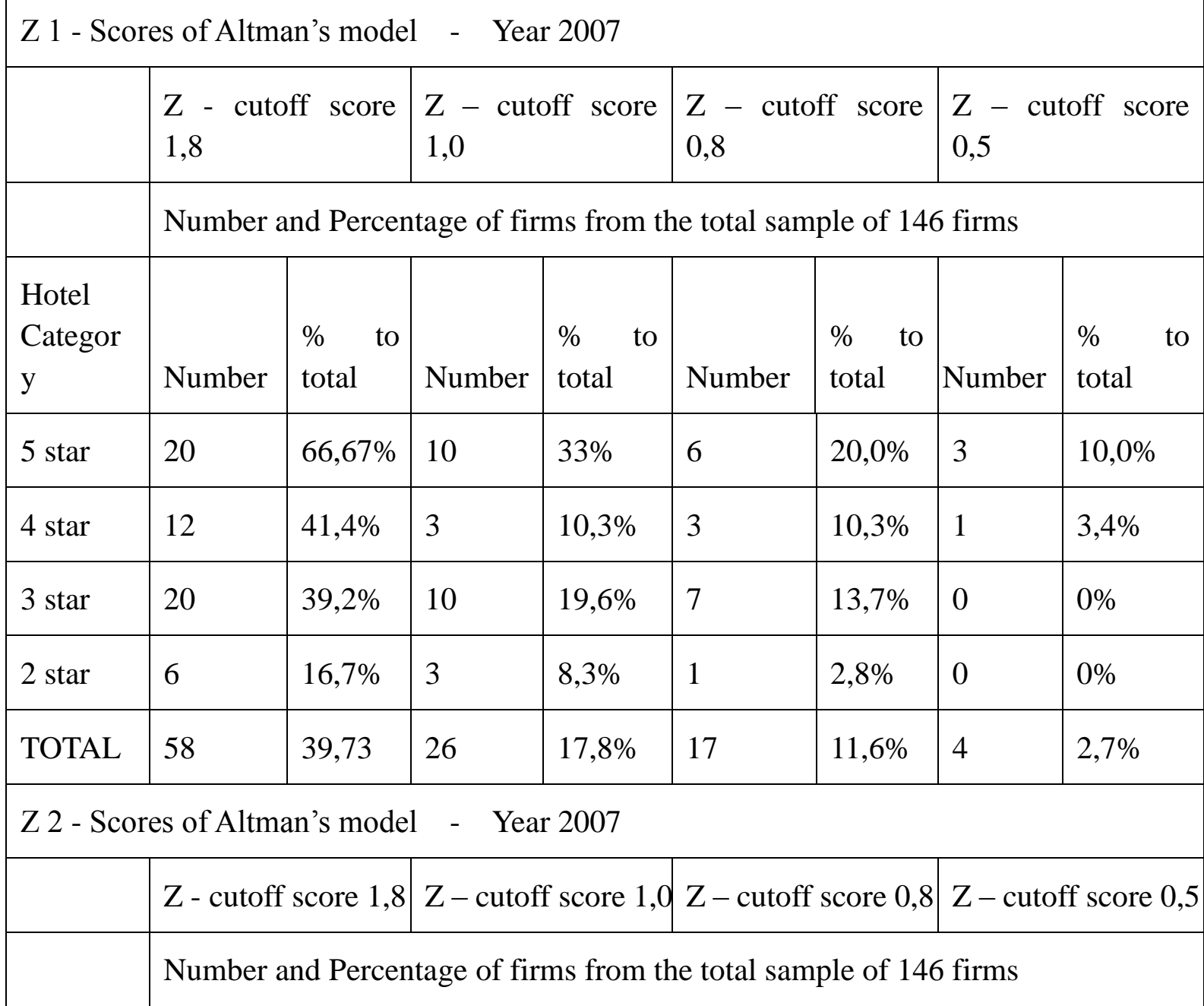




\begin{tabular}{|l|l|l|l|l|l|l|l|l|}
$\begin{array}{l}\text { Categor } \\
\text { y }\end{array}$ & Number & $\begin{array}{l}\% \\
\text { total to }\end{array}$ & Number & $\begin{array}{l}\% \text { to } \\
\text { total }\end{array}$ & Number & $\begin{array}{l}\% \text { to } \\
\text { total }\end{array}$ & $\begin{array}{l}\text { Numbe } \\
\mathrm{r}\end{array}$ & $\begin{array}{l}\% \\
\text { total }\end{array}$ \\
\hline $5 \mathrm{star}$ & 25 & $83,33 \%$ & 13 & $43,33 \%$ & 10 & $33,33 \%$ & 1 & $3,33 \%$ \\
\hline $4 \mathrm{star}$ & 17 & $58,62 \%$ & 6 & $20,69 \%$ & 3 & $10,35 \%$ & 1 & $3,45 \%$ \\
\hline $3 \mathrm{star}$ & 23 & $45,10 \%$ & 17 & $33,33 \%$ & 10 & $19,61 \%$ & 1 & $1,96 \%$ \\
\hline $2 \mathrm{star}$ & 6 & $16,67 \%$ & 4 & $11,11 \%$ & 3 & $8,33 \%$ & 0 & $0,00 \%$ \\
\hline TOTAL & 71 & $48,63 \%$ & 42 & $28,77 \%$ & 26 & $17,81 \%$ & 3 & $2,05 \%$ \\
\hline
\end{tabular}

Z 3 - Scores of Altman's model - Year 2007

\begin{tabular}{|c|c|c|c|c|c|c|c|c|}
\hline & \multicolumn{2}{|c|}{$\begin{array}{l}Z \text { - cutoff score } \\
1,8\end{array}$} & \multicolumn{2}{|c|}{$\begin{array}{l}Z-\text { cutoff score } \\
1,0\end{array}$} & \multicolumn{2}{|c|}{$\begin{array}{l}Z-\text { cutoff score } \\
0,8\end{array}$} & \multicolumn{2}{|c|}{$\begin{array}{l}Z-\text { cutoff score } \\
0,5\end{array}$} \\
\hline & \multicolumn{8}{|c|}{ Number and Percentage of firms from the total sample of 146 firms } \\
\hline $\begin{array}{l}\text { Hotel } \\
\text { Categor } \\
\text { y }\end{array}$ & Number & $\begin{array}{l}\% \text { to } \\
\text { total }\end{array}$ & Number & $\begin{array}{l}\% \text { to } \\
\text { total }\end{array}$ & Number & $\begin{array}{l}\% \text { to } \\
\text { total }\end{array}$ & $\begin{array}{l}\text { Numbe } \\
\mathrm{r}\end{array}$ & $\begin{array}{l}\% \text { to } \\
\text { total }\end{array}$ \\
\hline 5 star & 9 & $30 \%$ & 4 & $13,33 \%$ & 3 & $10 \%$ & 0 & $0 \%$ \\
\hline 4 star & 7 & $24,14 \%$ & 4 & $13,79 \%$ & 3 & $10,35 \%$ & 1 & $3,45 \%$ \\
\hline 3 star & 25 & $49,02 \%$ & 20 & $39,22 \%$ & 20 & $39,22 \%$ & 10 & $19,61 \%$ \\
\hline 2 star & 10 & $25 \%$ & 6 & $11,11 \%$ & 6 & $11,11 \%$ & 1 & $2,78 \%$ \\
\hline TOTAL & 51 & $34,93 \%$ & 34 & $24,66 \%$ & 32 & $21,92 \%$ & 12 & $8,22 \%$ \\
\hline
\end{tabular}

The results of applying Altman's models to hotel enterprises in Greece in 2007 show the number of enterprises that were highly likely to go bankrupt, (having a $\mathrm{Z}$ score $<1.8$ ), in 2008, was 58 for $Z 1$, 71 for $Z 2$ and 51 for the $Z 3$ model respectively. Of the 146 enterprises included in the sample, 15, or 10.3 percent filed for bankruptcy in 2008.

Afterward, three different cut-off prices were selected-1.0, 0.8 and 0.5 - to determine the zone that approaches an enterprise's bankruptcy with the highest certainty, as proven by comparing it to the real number of bankrupt firms in 2008. According to the data presented in Table 2, the following results are carried out from the application of Altman's models. 


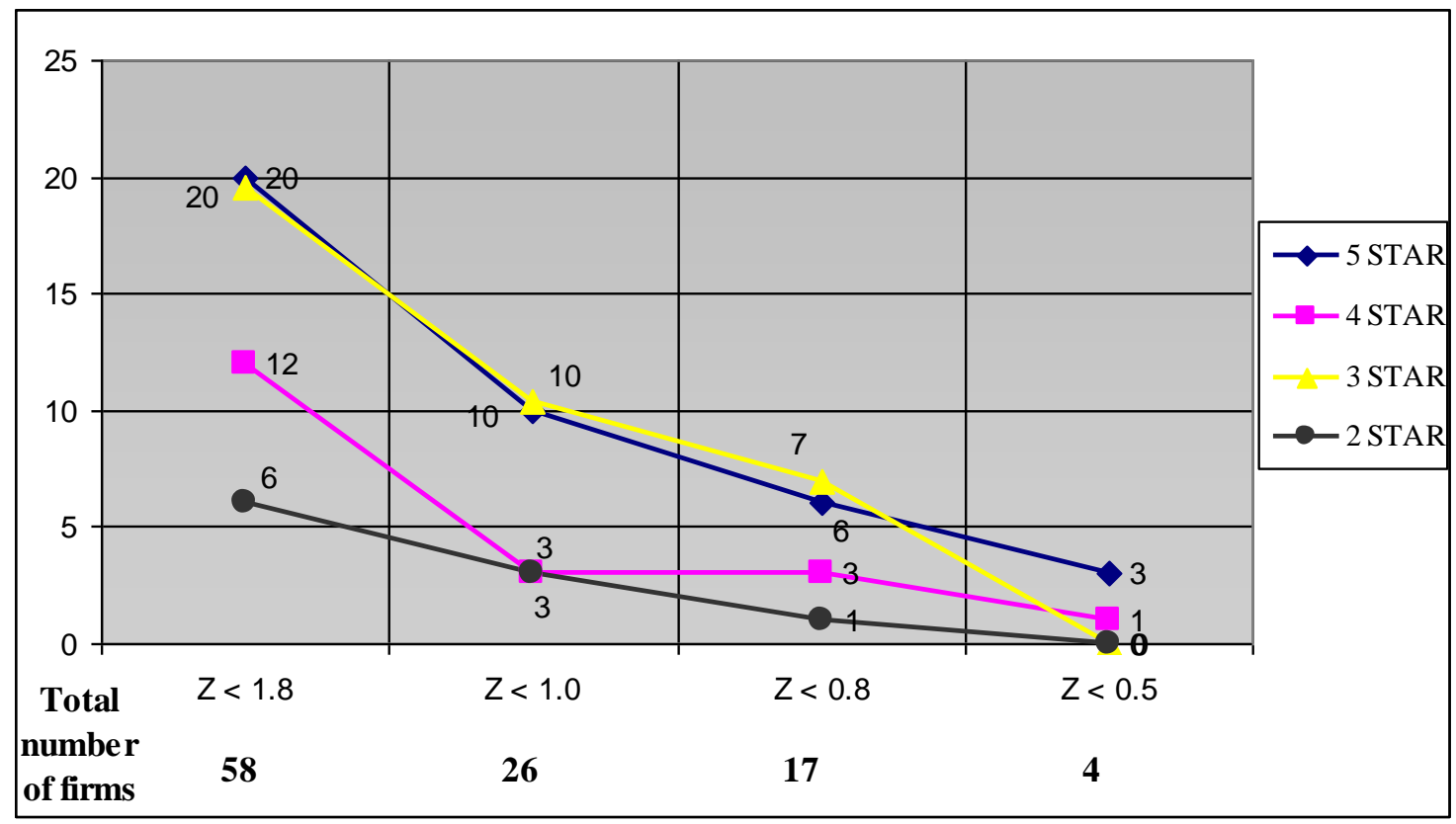

Figure 2. Z 1 score - Number of firms in different "Distress Zones" by hotel category

The $\mathrm{Z} 1$ model showed that the total number of enterprises that could be expected to file for bankruptcy, provided that the overall Z-score of the model was below 1.0, was 26 . Respectively, for overall $\mathrm{Z}$ scores below 0.8 , the number of bankrupted enterprises should have been 17 and, for prices below 0.5, only four. A comparison of the results with the number of enterprises that actually went bankrupt shows that the price nearest the real number of bankrupted enterprises was $<0.8$. The number of enterprises with overall $\mathrm{Z}$ scores less than 0.8 was 17 . By comparing the number of enterprises that, according to the model, presented bankruptcy "certainty" to those that went bankrupt, real bankruptcies constituted 88.24 percent (15/17) of forecasted bankruptcies. Despite the attempts to locate a more accurate zone, the one less than 0.8 showed the highest accuracy. 


\section{Macrothink}

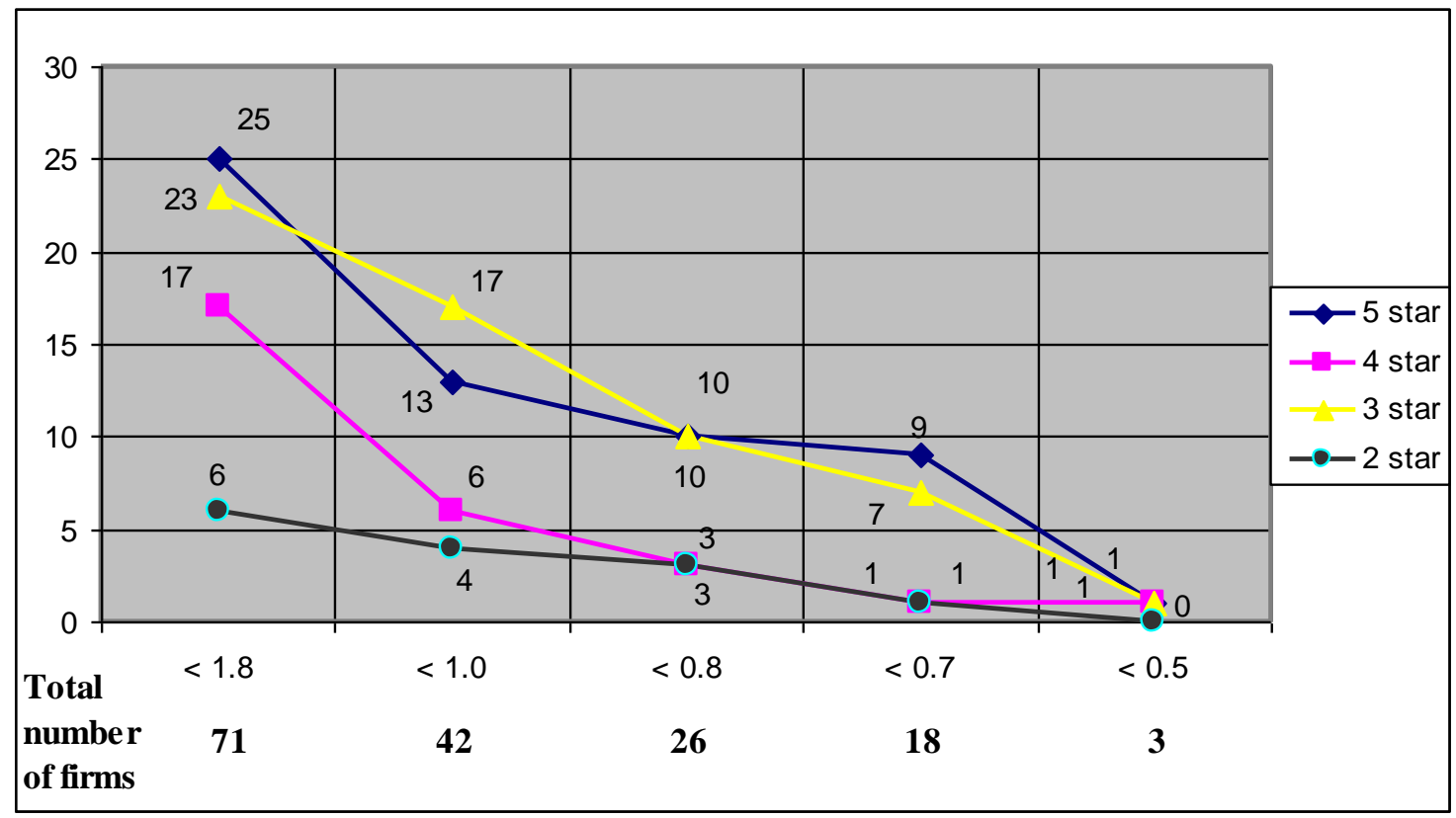

Figure 3. Z 2 score - Number of firms in different "Distress Zones" by hotel category

The $\mathrm{Z} 2$ model showed that the total number of enterprises that could be expected to file for bankruptcy, provided that the overall Z-score of the model was below 1.0, was 42 . Respectively, for overall $\mathrm{Z}$ scores less than 0.8 , the number of bankrupted enterprises should have been 26 and, for prices below 0.5, only three. A comparison of the results with the number of enterprises that actually went bankrupt shows that none of the prices is close to the real number of bankrupted enterprises. Such a price should have been far below the 0.8 cut-off zone and more than the 0.5 zone. Knowing that the number of enterprises that filed for bankruptcy in 2008 is 15 , we realize that the divergence of calculated forecasts of bankruptcy for the zone below 0.5 is 20 percent, or three predicted enterprises to 15 that actually went bankrupt, while for the zone below 0.8 the divergence is smaller $(15 / 26) ; 57.7$ percent of calculated forecasts of bankruptcy went bankrupt. Regarding the divergence of forecast by hotel category, the highest divergence for the zone below 0.8 is depicted in five-star hotels, followed by three- and two-star hotels, while there was not any divergence for the four-star hotels. For the zone less than 0.5, the highest divergence appeared in the five-star hotels, followed by three-star, while four- and two-star hotels showed no divergence at all. The number of enterprises with overall $\mathrm{Z}$ scores less than 1.23 is obviously higher than that of the less than 0.1 zone. Attempting to locate the zone with the highest accuracy for the $\mathrm{Z} 2$ model, we realize that the enterprises in the zone less than 0.7 are, besides those predicted in the zone less than 0.5, eight five-star hotels, zero four-star hotels, six three-star and one two-star hotel. That totals 15 enterprises. Adding the three forecasted in the less than 0.5 zone, we have 18 firms below the 0.7 zone. Therefore it is undeniable that the zone less than 0.7 gives the most accurate prediction of the number of actual bankruptcies for the $\mathrm{Z} 2$ model, with a rate of 83.33 percent $(15 / 18)$. 


\section{1ll Macrothink}

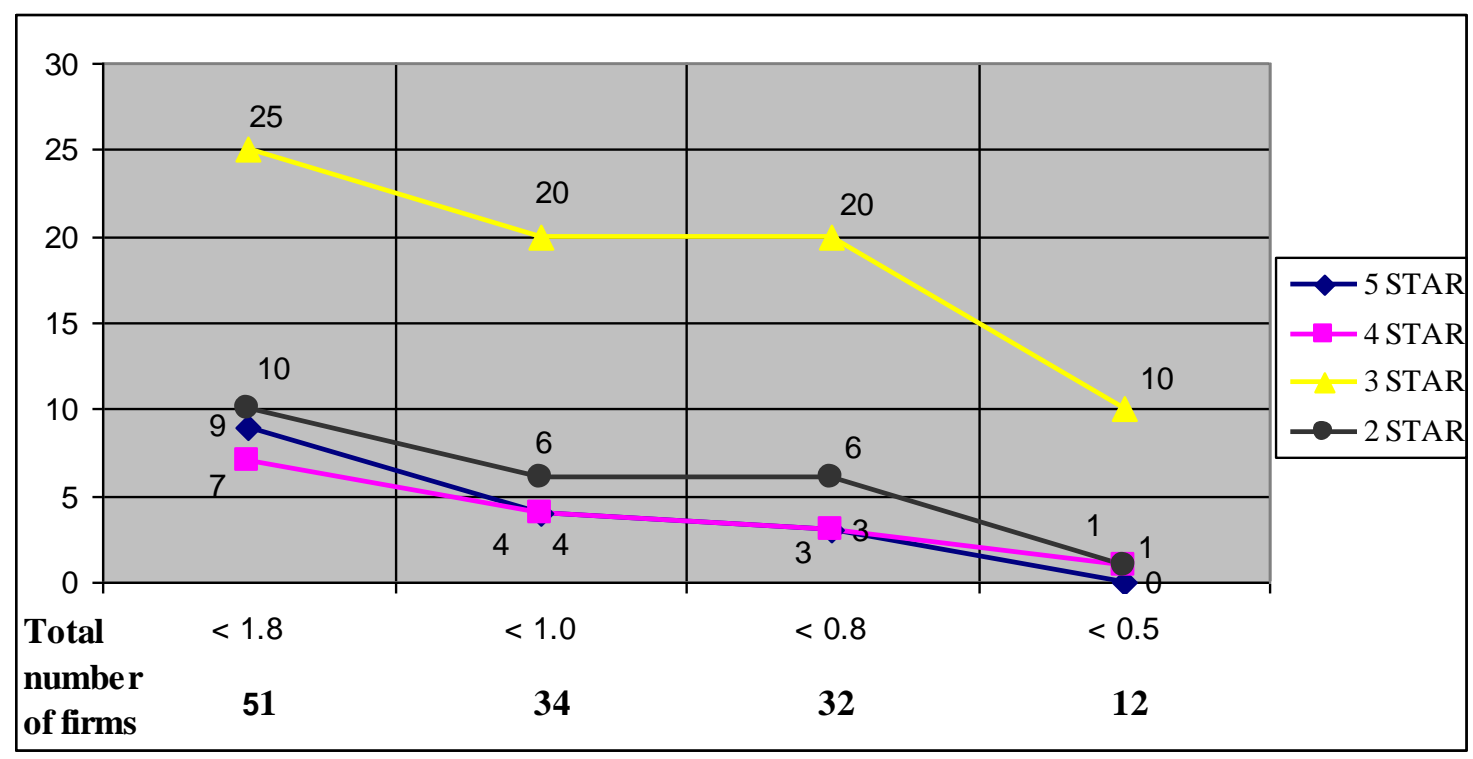

Figure 4. Z 3 score - Number of firms in different "Distress Zones" by hotel category

The Z 3 model showed that the total number of enterprises that could be expected to file for bankruptcy, provided that the overall Z-score of the model was below 1.0, was 34. For overall $\mathrm{Z}$ scores below 0.8 , the number of bankrupted enterprises should have been 32 and, for prices below 0.5 , the number should have been 12 . When comparing the results with the number of enterprises that actually went bankrupt, we find that the zone less than 0.5 is much closer to the real number of bankrupted enterprises. Since we know 15 enterprises filed for bankruptcy in 2008, we find that the smallest divergence of calculated forecasts of bankruptcy is for the zone below 0.5 , where 12 out of 15 ( 80 percent) of the predicted enterprises actually went bankrupt, while for the zone below 0.8 the divergence is higher (15/32 or 46.88 percent). The highest divergence for the zone below 0.8 is depicted in the three-star hotels, followed by two- and five-star hotels, while the smallest divergence can be seen in four-star hotels. For the zone less than 0.5 , the divergences divided by hotel category were like those of the zone less than 0.8. For the estimation of the distress zone below 1.1, the results are no better than those of the zone less than 1 (presented above). In the $\mathrm{Z} 2$ model, the zone less than 0.6 has 12 more firms in the distress zone, besides those predicted in the zone less than 0.5 , (one five-star hotel, one four-star, seven three-star and three two-star hotels). That adds up to 12 enterprises. Adding to them the 12 forecasted in the less than 0.5 zone, we have a total of 24 firms below the 0.6 zone. The accuracy of forecasting (15 real bankruptcies out of 24 forecasted bankruptcies) becomes 62.5 percent, which is obviously lower than that of the less than 0.5 zone, which is 80 percent.

\section{Conclusions}

The objective of this study was to evaluate Altman's three models on the private hotels in Greece, examining the possibility of forecasting bankruptcy and determining the precise 
percentage of enterprises for which accurate predictions could be made. Estimates concerned forecasts for one year before bankruptcy realisation by each of Altman's models.

After dividing the distress zone into three fields, it became clear that for the year under study, a cut-off of a Z 1 score below 0.8 most closely approached the number of enterprises that went bankrupt, among those for whom bankruptcy was forecasted. Enterprises that actually filed for bankruptcy in 2008 were predicted in 2007, one year ahead of actual bankruptcy filing, with 88.24 percent (15/17) accuracy.

The general conclusion that can be drawn from the results is that the Altman model can be applied with considerable success (i.e., a high degree of reliability and accuracy) to forecasting the bankruptcy of hotel enterprises. It was proved that one-quarter of all enterprises located in the distress zone for bankruptcy would certainly file for bankruptcy. The price of the $\mathrm{Z}$ score model for these enterprises was found to be less than 0.8. The divergence of calculated forecasts of bankruptcy from the number of enterprises that actually went bankrupt is 11.76 percent.

From the application of the $\mathrm{Z} 2$ model, it was realized that with the corresponding division of the distress zone into three fields, the highest accuracy zone is far below the 1.23 zone, and specifically in the zone $<0.7$, with an accuracy rate of 83.33 percent and a divergence of 16.77 percent, very close to the predicted bankruptcies of the $\mathrm{Z} 1$ model $(<0.8,88.24$ percent).

The most accurate prediction from the $\mathrm{Z} 3$ model application is reached below the 1.1 zone, and specifically in the zone $<0.5$, with 80 percent accuracy and a divergence of 20 percent.

Between hotels in different categories, the bankruptcy risk presented by five- and three-star hotels is greater than the risk presented by four-star hotels, while the risk is considerably smaller for two-star hotels.

Taking into consideration the limitation of the research regarding the $\mathrm{T} 4$ variable, we realize that between the initial model Z 1 and the two later versions $Z 2$ and Z 3, despite the fact they have been applied to private hotel firms, the $Z 1$, which was designed and initially applicable to publicly owned industrial firms, showed the highest accuracy with a rate of 88.24 percent (in the zone $<0.8$ ), followed by $\mathrm{Z} 2$ model with an accuracy rate of 83.33 percent (in the $<0.7$ zone), and finally the $\mathrm{Z} 3$, with the lowest accuracy among the other $\mathrm{Z}$ score models, 80 percent (in the $<0.5$ zone). It is noteworthy that the $Z 3$ model, which was designed and applied in the service sector firms, showed the lowest accuracy in this study.

A major limitation of this study is that criteria such as hotel size, geographic location, seasonality, client's categories, etc., were not included; Therefore, recommendations for future research concerning bankruptcy forecasting in the hotel sector, should include the above mentioned and even more criteria that may differentiate insolvency forecasting results.

Implications concerning hotel businesses' management and specifically insolvency forecasting should not limit their study in only one method, but extent to more analytic approaches of all three Altman's models, including financial data for a longer period to completely illustrate the hotels' financial strengths and weaknesses which may appraise 
future bankruptcy.

Future research should be extended including data for years beyond 2008 and predict bankruptcy in the following years with their new benchmarks in order to verify our findings with an out-of-sample test.

Research findings can have also implications concerning the development of theory of bankruptcy prediction in a specific sector of an economy in crisis, as it is the hotel sector in the Greek economy for the last five years, including factors related to the economic crisis.

\section{Acknowledgment}

This paper follows up on a previous study and is considered a revised and expanded version of the paper entitled "Insolvency Prediction: Evidence from Greek Hotels" presented at the $8^{\text {th }}$ International Conference on Enterprise Systems, Accounting and Logistics (8th ICESAL 2011) 11-12 July 2011, Thassos Island, Greece.

\section{References}

Agarwal, V. Taffler. R. J. (2007). Twenty-five years of the Taffler z-score model: Does it really have predictive ability? Accounting and Business Research, 37 (4), pp.285-300.

Allayannis, G. Brown, G. W. Klapper, L. F. (2003). Capital structure and financial risk: Evidence from foreign debt use in East Asia. Journal of Finance, 58(6), pp.2667-2709.

Altman, E. I. (1968). Financial Ratios, Discriminant Analysis and the Prediction of Corporate Bankruptcy. Journal of Finance, Vol. 23 (4), pp. 589-609.

Altman, E. I. (1983). Corporate financial distress: A complete guide to predicting, avoiding, and dealing with bankruptcy. New York: John Wiley \& Sons.

Altman, E. I. (2000). Predicting Financial Distress of Companies. Retrieved on June 8th, 2011 from http://pages.stern.nyu.edu/ ealtman/Zscores.pdf.

Aziz, M. A. Dar, H. A. (2006). Predicting corporate bankruptcy: Where we stand? Corporate Governance, 6 (1), pp.18-33.

Barjaktarovic, D. Barjaktarovic L. (2010). Possibilities of financial support to small and medium hotel companies in Serbia. Journal of Economics, Vol. 1 (1), pp. 1-11.

Beck D. F. (1994). Cash is king Health Care Supervisor 13 (1), pp.1-9

Begley, J., Mining, J. Watts, S. (1996). Bankruptcy classification errors in the 1980s: An empirical analysis of Altman's and Ohlson's models. Review of Accounting Studies, 1 (4), pp.267-284

Bellovary J., Giacomino D. Akers M. (2007). A Review of Bankruptcy Prediction Studies: 1930 to Present, Journal of Financial Education, Volume 33, pp.1-42

Beynon, M. J. Peel, M. J. (2001). Variable precision rough set theory and data discretisation: An application to corporate failure prediction. Omega, 29, pp.561-576. 


\section{Macrothink}

International Journal of Accounting and Financial Reporting ISSN 2162-3082 2012, Vol. 2, No. 2

Bohannon, J. Edwards, D. (1993). Cash budgeting;. Journal of Property Management, 58 (3), pp.52-53

Burns, J. Balvinsdottir, G. (2005). An institutional perspective of accountants' new roles - the interplay of contradictions and praxis'. European Accounting Review 14 (3), pp.725-757.

Calandro, J. (2007). Considering the utility of Altman's Z-score as strategic assessment and performance management tool. Strategic \& Leadership, 35(5), pp.37-43.

Casey, C. Bartczak, N. (1985). Using operating cash-flow data to predict financial distress: some extensions. Journal of Accounting Research, 23 (1), pp.384-401

Chung, K. C., Tan, S. S. Holdsworth, D. K. (2008). Insolvency prediction model using multivariate discriminant analysis and artificial neural network for the finance industry in New Zealand. International Journal of Business and Management, 3(1), pp.19-29.

Collier P. Gregory A. (1995). Strategic management accounting: a UK hotel sector case study. International Journal of Contemporary Hospitality Management, 7 (1), pp. 16-21

DeFranco A. L. Schmidgall R. S. (1998). Cash flow practices and procedures in the lodging industry. Journal of Hospitality \& Tourism Research, 22 (1), pp.72-83

Dimitras, A.I., Zanakis, S.H., Zopounidis, C. (1996). A survey of business failures with an emphasis on prediction methods and industrial applications. European Journal of Operational Research 90 (3), pp.487-513

Dimitras, A., Slowinksi, R., Susmaga R., Zopounidis, C. (1999). Business failure prediction using rough sets. European Journal of Operational Research 114(2): pp.263-280.

Eidleman, G. J. (1995). "Z-Scores - A Guide to Failure Prediction". The CPA Journal Online. Retrieved on June 10th, 2011 from http://www.nysscpa.org/cpajournal

Epstein M.C. Pava M.L. (1994). Profile of an annual report. Financial Executive, 10 (1), pp. $41-43$

Ferguson, M. F. Shockley, R. L. (2003). Equilibrium anomalies. Journal of Finance, 58(6), pp.2549-2580.

Gerantonis N., Vergos K. , Christopoulos A. (2009). Can Altman Z-score Models Predict Business Failures in Greece?. In (Ed) Frangos C. $2^{\text {nd }}$ International Conference Quantitative and Qualitative Methodologies in the Economic and Administrative Sciences, TEI of Athens, pp. 149-154

Gloubos, G. Grammatikos, T. (1988). Success of bankruptcy prediction models in Greece. Studies in Banking and Finance: International business failure prediction models, vol.7, pp.37-46.

Griffin, J. Lemmon, L. (2002). Book-to-market equity, distress risk, and stock returns. Journal of Finance, 57(5), pp. 2317-2336.

$\mathrm{Gu}$, Z. (2002). Analyzing bankruptcy in the restaurant industry: a multiple discriminant model. International Journal of Hospitality Management 21 (1), pp. 25-42. 


\section{Macrothink}

International Journal of Accounting and Financial Reporting ISSN 2162-3082 2012, Vol. 2, No. 2

Gu Z. Luyuan G. (2000). A Multivariate Model for Predicting Business Failures of Hospitality Firms, Tourism and Hospitality Research: The Surrey Quarterly Review, 2(1), pp.37-50.

Jayadev, M. (2006). Predictive power of financial risk factors: An empirical analysis of default companies. The Journal for Decision Makers, 31(3), pp. 45-56.

Kao, D. L. (2000). Estimating and pricing credit risk: An overview. Financial Analysts Journal, 56(4), pp. 50-66.

Kim, H. Gu, Z. (2006). A logistic regression analysis for predicting bankruptcy in the hospitality industry. The Journal of Hospitality Financial Management 14 (1), pp. 17-34.

Kim, H. Gu Z. (2006). Predicting Restaurant Bankruptcy: A Logit Model in Comparison with a Discriminant Model, Journal of Hospitality \& Tourism Research, Vol. 30(4), pp 474-493

Lazaridis G. Papadopoulos D. (2002). Financial Management, Volume B. Thessaloniki Lazaridis - Papadopoulos Editions

Lifschutz S. Jacobi A. (2010). Predicting Bankruptcy: Evidence from Israel International Journal of Business and Management Vol. 5 (4), pp. 133-141

Lawson, R. (2008). Measuring company quality. Journal of Investing, 17(4), pp.38-55.

Marchesini, R., Perdue, G. Bryan, V. (2004). Applying bankruptcy prediction models to distressed high yield bond issues. Journal of Fixed Income, 13(4), pp.50-56.

Mattimoe R. (2008). The Role of the Accountant and the Marketeer in Operational Decision-making in UK Hotels and Restaurants : A Research Agenda. 21st Annual Conference of the Irish Accounting and Finance Association, Athlone Institute of Technology, 08-09 May 2008.

Mills, J. R. Yamamura, J. H. (1998). The power of cash flow ratios. Journal of Accountancy, 186 (4), pp.53-62.

Molina, C. A. (2005). Are firms underleveraged? An examination of the effect of leverage on default probabilities. Journal of Finance, 60(3), pp.1427-1459.

Neophytou, E. Charitou, A. Charalambous, C. (2001). Predicting corporate failure: Empirical evidence for the UK. Discussion Paper No. 01-173, March, School of Management, University of Southampton, Southampton.

Pavlatos O. Paggios I. (2009). A survey of factors influencing the cost system design in hotels. International Journal of Hospitality Management, 28, pp. 263-271

Perez, M. (2006). Artificial neural networks and bankruptcy forecasting: a state of the art. Neural Computer \& Application, 15, pp.154-163

Ryu K. Jang S. (2004). Performance Measurements Through Cash Flow Ratios and Traditional Ratios: A Comparison of Commercial and Casino Hotel Companies, Journal of Hospitality Financial Management, 12 (1), pp.15-25 


\section{Macrothink}

International Journal of Accounting and Financial Reporting

ISSN 2162-3082 2012, Vol. 2, No. 2

Scapens R. (2006). Understanding Management Accounting Practices: a personal journey, British Accounting Review, 38 (1), pp. 1-30

Soo K. (2011). Prediction of hotel bankruptcy using support vector machine, artificial neural network, logistic regression, and multivariate discriminant analysis, The Service Industries Journal, Vol. 31 (3) pp 441-168

Sudarsanam. S. Lai, J. (2001). Corporate financial distress and turnaround strategies: An empirical analysis. British Journal of Management, 12(3), pp.183-199.

Sylvestre, J. Urbancic, F. R. (1994). Effective methods for cash flow analysis. Healthcare Financial Management, 48 (7), pp.62-72

Theodossiou, P. (1991). Alternative models for assessing the financial condition of business in Greece. Journal of Business and Accounting, 18(5), pp.697-720.

Youn H. Gu Z. (2010). Predicting Korean lodging firm failures: An artificial neural network model along with a logistic regression model International Journal of Hospitality Management 29 pp. 120-127

Vranas A. (1991). Models of probability for the forecast of economic failure of Greek industrial enterprises. SPOUDAI, 41 (4), pp.431, University of Piraeus (inGreek).

Zopounidis C. Doumpos M. (1999). Business failure prediction using the UTADIS multicriteria analysis method. Journal of the Operational research Society, Vol. 50(11), pp1138

\section{Copyright Disclaimer}

Copyright reserved by the author(s).

This article is an open-access article distributed under the terms and conditions of the Creative Commons Attribution license (http://creativecommons.org/licenses/by/3.0/). 